\title{
ANALISIS PENGEMBANGAN BISNIS BERBASIS MADU PADA UD. "OMG" DI DESA 32 BUNGA EJA KECAMATAN EMPANG : STUDI KASUS PADA SABUN AULY
}

\author{
Serli Oktapiani'; \\ Fakultas Ekonomi dan Bisnis Universitas Teknologi Sumbawa,1 \\ serli.oktapiani@uts.ac.id
}

ABSTRAK

Penelitian ini menggunakan metode deskriptif dengan pendekatan kualitatif. Data dikumpulkan dari pemilik usaha dengan metode observasi dan wawancara secara langsung. Penelitian ini dilaksanakan bulan Januari 2021. Analisis yang digunakan adalah Analisis Hirarki Proses (AHP). Hasil penelitian menyatakan bahwa pengembangan dan kenyamanan membantu meningkatkan teknologi pengolahan madu teknologi pasca panen, kualitas produksi madu dan peningkatan pengemasan produk menjadi prioritas utama dalam pengolahan pasca panen perkembangan bisnis madu OMG.

Kata kunci: Usaha madu, Strategi pengembangan, Strategi pasca panen, Strategi pemasaran

\section{Abstract}

This research uses descriptive method with a qualitative approach. Data were collected from business owners by direct observation and interview methods. This research was conducted in January 2021. The analysis used was the Process Hierarchy Analysis (AHP). The result of the research states that development and convenience help improve post-harvest technology of honey processing technology, honey production quality and product packaging improvement are the main priorities in post-harvest processing, OMG honey business development.

Keywords: Honey business, Development strategy, Post-harvest strategy, Marketing strategy

Diterima: 2 Oktober 2021; Direvisi; 9 Oktober 2021; Diterbitkan: Oktober 2021

\section{PENDAHULUAN}

Indonesia merupakan negara dengan iklim tropis yang merupakan habitat berbagai tumbuhan dan satwa. Hal tersebut menjadikan Indonesia sebagai negara dengan sumber daya alam yang melimpah (SDA). Lebah merupakan hewan yang sangat berkembang di Indonesia. Didukung kondisi alam di Indonesia, keberadaan lebah memiliki peluang bisnis yang sangat besar. Lebah memiliki banyak manfaat bagi manusia dan lingkungan, menjadikannya salah satu komoditas andalan yang dapat meningkatkan nilai ekonomi masyarakat (Situmorang dan Hasanudin, 2014) : 
a) Madu, berguna bagi pemeliharaan kesehatan, kosmetika dan farmasi,

b) Royal jelly, dimanfaatkan untuk stamina dan penyembuhan penyakit, sebagai bahan campuran kosmetika, dan bahan campuran obat-obatan,

c) Pollen (tepung sari), dimanfaatkan untuk campuran bahan obat-obatan/ kepentingan farmasi,

d) Lilin lebah (malam), dimanfaatkan untuk industri farmasi dan kosmetika sebagai pelengkap bahan campuran propolis (perekat lebah), dimanfaatkan untuk penyembuhan luka, penyakit kulit dan membunuh virus influenza.

Salah satu pengusaha madu di Sumbawa adalah OMG Oleh-Oleh Khas Sumbawa yang berdiri sejak 2015 yang didirikan oleh Firmansyah dan Hesti. Melihat potensi madu yang begitu besar dan peminatnya juga banyak, mereka mencoba membuat inovasi baru dari madu ini yaitu produk kecantikan dimana produk kecantikan tersebut antara lain, sabun Auly yang mulai diproduksi sejak bulan Maret 2020, menyusul produk kecantikan lainnya seperti masker scrub, masker madu dan lulur madu.

Analisis strategi pengembangan bisnis sangat penting, agar pemilik bisnis dapat menentukan langkah apa yang dapat diambil untuk mendorong perkembangan bisnisnya. Menurut Taufiqurokhman (2016), secara keseluruhan strategi adalah proses penentuan suatu rencana yang mengarah pada tujuan jangka panjang dan disertai dengan langkah langkah untuk mencapai tujuan yang diinginkan. Mendefinisikan strategi dapat dicapai melalui manajemen strategis.

\section{LANDASAN TEORI}

\section{Pendekatan dan Jenis Penelitian}

Dalam penelitian ini peneliti menggunakan metode deskriptif dengan pendekatan kualitatif. Menurut penelitian Sugiyono (2010), penelitian kualitatif bertujuan untuk memahami fenomena yang dialami subjek penelitian, seperti komunitas, motivasi dan gaya hidup.

\section{Analisa Data}

\section{Analisis Deskriptif Kualitatif}

Analisis deskriptif kualitatif bertujuan untuk mengetahui visi, misi dan tujuan kelompok tani, strategi dan data yang diterapkan terkait dengan kegiatan pemasaran, pencapaian tujuan penjualan, keuangan, produksi, operasional dan kualitas produk. Dalam analisis kualitatif dan deskriptif ini digunakan metode analisis interaktif. Menurut Nugrahani (2014) ada beberapa tahapan analisis interaktif yaitu:

a) Langkah pertama adalah mengurangi data.

Pada tahap ini proses pemilihan atau pemilihan, pemfokusan atau pemfokusan, penyederhanaan dan pengabstrakan semua jenis informasi akan mendukung data penelitian yang diperoleh dan dicatat pada proses data mining lapangan. Pada dasarnya.

b) Sajian Data

Kemudian informasi berupa temuan kunci yang diperoleh dari hasil reduksi data dikumpulkan menjadi representasi data sebagai bahan bagi peneliti untuk menarik kesimpulan dan melakukan tindakan.

c) Penarikan Kesimpulan

Menarik kesimpulan merupakan kegiatan yang menafsirkan hasil analisis dan interpretasi data.

Analisis Hierarki Proses (AHP) 
Analisis dalam penelitian ini menggunakan metode Analytic Hierarchy Proses (AHP), dengan tujuan untuk mengetahui prosedur prioritas dalam mengembangkan usaha madu di Kecamatan Empang Kab Sumbawa. Metode Analitis Hierarki Proses (AHP) adalah model pengambilan keputusan komprehensif yang mempertimbangkan masalah kualitatif dan kuantitatif. Metode AHP dapat membantu menetapkan prioritas dan tujuan melalui berbagai pilihan dengan menggunakan beberapa kriteria (Prajanti, 2013) (Su'aidy et al., 2021).

Langkah-langkah dalam metode Analisis Hierarki Proses (Saaty, 1993) :

a) Langkah pertama, yaitu menentukan sebuah tujuan berdasarkan permasalahan yang ada.

b) Langkah kedua yaitu menentukan kriteria. Kriteria diperoleh dari hasil survei dan diskusi dengan pengusaha maupun masyarakat terhadap pengembangan usaha madu di Desa Bunga Eja, Kecamatan Empang.

c) Langkah ketiga yaitu menentukan alternatif. Menentukan alternatif sama halnya dengan menentukan kriteria diatas. Alternatif juga diperoleh dari peramudan masyarakat tentang penanganan pengembangan usaha madu di Desa Bunga Eja, Kecamatan Empang. Dalam hal ini membahas langkah dan strategi yang dibutuhkan dalam upaya mengembangkan usaha madu di Desa Bunga Eja, Kecamatan Empang.

d) Langkah keempat yaitu penentuan skala prioritas dari kriteria dan alternatif untuk mencapai variabel hierarki dengan tujuan pengembangan usaha madu di Desa Bunga Eja, Kecamatan Empang.

\section{METODE PENELITIAN}

Dalam penelitian ini peneliti menggunakan metode deskriptif dengan pendekatan kualitatif. Menurut penelitian Sugiyono (2010), penelitian kualitatif bertujuan untuk memahami fenomena yang dialami subjek penelitian, seperti komunitas, motivasi dan gaya hidup. Melalui penggunaan berbagai metode alam, keseluruhan dan melalui deskripsi kata dan bentuk bahasa dalam konteks alam tertentu. Oleh karena itu, dalam penelitian ini penulis mendeskripsikan dan menganalisis perkembangan usaha madu OMG Sumbawa di Desa Bunga Eja Kecamatan Empang.

Metode deskriptif merupakan salah satu jenis penelitian yang mendeskripsikan kondisi objek penelitian selama penelitian, karena didasarkan pada fakta, kemudian berusaha untuk menarik kesimpulan secara umum (Sugiyono, 2014).

\section{HASIL PENELITIAN DAN PEMBAHASAN}

Sejarah OMG

Sekitar tahun 2014 Firmansyah mencoba mengikuti lomba salah satu event marketing yang diadakan di kota Mataram dengan mecoba memperkenalkan salah satu produk khas Kecamatan Empang yaitu masin jotang, dari sekian ribu peserta yang mengikuti ternyata masin jotanglah yang bisa memasuki 10 besar. Dari keberhasilan itulah akhirnya Firmansyah mencoba mengembangkan potensi alam yang ada di kampungnya seperti Madu, melihat potensi madu yang begitu besar, Firmansyah mencoba memperkenalkan madu asli khas kampungnya, melihat banyaknya penjual madu yang begitu banyak dan hanya menjajakan madunya saja, maka Firmansyah berinisiasi membuat inovasi baru dari madu tersebut seperti produk kecantikan. 
Pengembangan Produk

Marketing online merupakan bentuk adaptasi dalam menghadapi Covid-19 ini. Proses memasarkan salah satu produk dari OMG Oleh-Oleh Khas Sumbawa yang Kekinian dan Kece KHAS SUMBAWA. AULY pollen soap bar adalah sabun natural yang dibuat dan di formulasikan tanpa deterjen dan dibuat dari bahan alami. Sabun AULY ini merupakan produk turunan MADU HUTAN SUMBAWA yang diracik dengan bahan-bahan ALAMI: Bee Pollen + Madu Hutan Sumbawa + Kunyit + Kayu Manis + Propolis Madu Hitam Sumbawa + Minyak Zaitun. AULY Pollen Soap ini bermanfaat :

\section{a. Langkah} menentukan

\section{pertama,}

sebuah

yaitu berdasarkan permasalahan yang ada. Peneliti : Awal mula usaha OMG ini seperti apa?

Informan : Awal mula saya membuka usaha ini Sekitar tahun 2014 saya mencoba mengikuti lomba salah satu event marketing yang diadakan di kota Mataram dengan mecoba memperkenalkan salah satu produk khas Kecamatan Empang yaitu masin jotang, dari sekian ribu peserta yang mengikuti ternyata masin jotanglah yang bisa memasuki 10 besar. Dari keberhasilan itulah akhirnya saya mencoba mengembangkan potensi alam yang ada di kampung seperti madu, melihat potensi madu yang begitu besar, saya mencoba memperkenalkan madu asli khas kec Empang, melihat banyaknya penjual madu yang begitu banyak dan hanya menjajakan madunya saja, maka saya berinisiasi membuat inovasi baru dari madu tersebut seperti produk kecantikan agar tampak beda dari penjual-penjual madu lainnya.

b. Langkah kedua yaitu menentukan kriteria. Kriteria diperoleh dari hasil survei dan diskusi dengan pengusaha maupun masyarakat terhadap pengembangan usaha madu di Desa Bunga Eja, Kecamatan Empang.

Peneliti. Seperti apa kriteria pengembangan usaha madu yang bapak kembangkan?

Informan. Nah disini saya melihat apa saja yang menjadi kebutuhan utama masyarakat dan yang sangat laku dipasaran, setelah saya melakukan pengamatan, ternyata yang banyak dibutuhkan oleh masyarakat itu adalah produk kecantikan seperti: sabun, lulur, masker, dan lain sebagainya.

Berdasarkan hasil wawancara diatas menunjukkan bahwa pengembangan usaha madu didasarkan terhadap kebutuhan utama masyarakat seperti produk kecantikan.

c. Langkah ketiga yaitu menentukan alternatif. Menentukan alternatif sama halnya dengan menentukan kriteria diatas. Alternatif juga diperoleh dari peramu dan masyarakat tentang penanganan pengembangan usaha madu di Desa Bunga Eja, Kecamatan Empang. Dalam hal ini membahas langkah dan strategi yang dibutuhkan dalam upaya mengembangkan usaha madu di Desa Bunga Eja, Kecamatan Empang. 
Peneliti. Dalam mengembangkan usaha madu ini dalam membuat produk kecantikan, produk kecantikan mana yang duluan bapak coba untuk perkenalkan?

Informan : Pertama saya mencoba membuat masker madu, tapi setelah dilakukan pengamatan ternyata masker tidak selalu dibutuhkan oleh masyarakat, ini bisa dilihat dari waktu penggunaannya dimana masker hanya digunakan maksimal 2 kali seminggu atau minimal 1 kali seminggu, nah karna hal itu saya mencoba berpikir bagaimana kalau saya mencoba membuat sabun, dimana penggunaan sabun ini sendiri menjadi kebutuhan pokok masyarakat yang setiap waktu dibutuhkan dan digunakan. Kemudian saya mencoba membuat sabun dan beberapa kali gagal setelah yang kesekian kalinya akhirnya berhasil kemudian saya mencoba penggunaannya ke beberapa reseller dan keluarga dan ternyata mereka suka dengan produk ini dan sangat cocok dikulit mereka.

\section{d. Langkah keempat yaitu penentuan} skala prioritas dari kriteria dan alternatif untuk mencapai variabel hierarki dengan tujuan pengembangan usaha madu di Desa Bunga Eja, Kecamatan Empang.

Peneliti. Dalam pengembangan usaha OMG ini, bapak lebih fokus untuk mengembangkan usaha yang mana?

Informan. Sebenarnya usaha OMG ini adalah saya jadikan sebagai pusat oleholeh Sumbawa dimana semua jenis makanan khas Sumbawa ada termasuk masin, kerupuk atom, madu, dan lainnya, tapi disini saya lebih memfokuskan untuk mengembangkan lebih dalam lagi pengolahan madu ini sendiri menjadi produk kecantikan, nah dari produk kecantikan ini sendiri yang lebih banyak kami prioritaskan itu sendiri adalah sabun AULY dimana sabun AULY ini banyak dibutuhkan oleh masyarakat.

\section{Kriteria Pengembangan Usaha}

Sebagai prioritas pengembangan bisnis madu, hal ini dilakukan dengan memilih standar yang telah ditentukan, yaitu pemrosesan Aspek pasca panen dan pemasaran. Dari semua aspek sebagai standar, ada alternatif dalam langkah pengembangan bisnis madu adalah pilihan pertama.

Menurut pendapat komprehensif dari narasumber Pertimbangkan standar strategi pengembangan pemasaran adalah kriteria paling penting untuk dipertimbangkan Strategi pengembangan bisnis madu di OMG ke bawah. Bobot merupakan standar strategi pengembangan pasca panen.

Hasil pengolahan data AHP digunakan untuk menentukan strategi Prioritaskan pengembangan dan berikan yang relevan Beberapa strategi yang perlu perbaikan atau pengembangan Pengembangan usaha madu di OMG. Kemudian, dari strategi menjadi yang paling standar Prioritas pesanan akan dijabarkan lebih lanjut dalam alternatif Setiap standar.

\section{Kriteria Pemasaran}

Strategi pemasaran adalah strategi yang paling penting dan terpenting Memprioritaskan penyelesaian dalam strategi pengembangan bisnis madu di OMG. Strategi pemasaran Ada dua pilihan 
yang bisa dijadikan acuan untuk pekerjaan pengembangan bisnis madu termasuk promosi melalui media cetak, elektronik dan sosial, dan melalui kerja sama dengan pemerintah, lembaga swadaya masyarakat, industri pengolahan, bank dan universitas. Seperti diketahui bahwa melakukan promosi baik melalui media cetak, elektronik dan media sosial menjadi alternatif yang paling diprioritaskan dalam pengembangan usaha madu dari strategi.

\section{Kriteria Pasca Panen}

Ada tiga pilihan standar pasca panen, termasuk menyediakan Pengetahuan dan konsultasi untuk meningkatkan kesadaran kolektor Pengolahan pasca panen yang baik dan ramah Kenyamanan lingkungan, perkembangan dan konseling meningkatkan keterampilan menyeduh madu dalam teknik pasca panen Dan kualitas produksi madu, dan peningkatan kemasan produk, dan memberikan pengetahuan dan bantuan tentang produk turunan Diproduksi oleh lebah madu Apis Dorsata. Sebagai upaya pengembangan Usaha madu di OMG melalui metode alternative.

Pengembangan dan kenyamanan membantu meningkatkan teknologi pengolahan madu Teknologi pasca panen, kualitas produksi madu dan peningkatan pengemasan Produk menjadi prioritas utama dalam pengolahan pasca panen Perkembangan bisnis madu OMG. Prioritas kedua adalah Memberikan pengetahuan dan bantuan tentang produk turunan Diproduksi oleh lebah madu Apis Dorsata. Sebagai prioritas terakhir di Pengolahan pasca panen memberikan pengetahuan dan Memberikan konsultasi untuk meningkatkan kesadaran kolektor
Penanganan pasca panen dan ramah lingkungan.

Adapun strategi yang digunakan OMG untuk produk sabun AULY yaitu Strategi Diverifikasi. Strategi ini dilakukan untuk bagaimana produk sabun AULY ini dapat membentuk produk baru dari sabun AULY itu sendiri. Penambahan produk baru yang dipasarkan dipasar baru sebenarnya memiliki manfaat tersendiri.

Adapun manfaat yang sangat berpengaruh dengan dilakukan Strategi Diverifikasi ini ialah :

a) Meningkatkan Probabilitas dan Daya saing.

Dengan memiliki suatu Usaha dagang OMG ini dengan berbagai jenis produk seperti terciptanya sabun AULY akan mencegah pesaing untuk memonopoli pasar. Kemudian, bisa juga mempersempit ruang gerak para pesaing baru. Market Share yang berhasil teraih dari adanya produk baru dapat menambah pemasukan usaha OMG.

b) Meminimalisir Resiko

Resiko selalu ada di segala proses termasuk adanya ancaman usaha OMG. Dengan dilakukan strategi Diverifikasi ini secara tidak langsung akan mengurangi dampak resiko pada masa mendatang seperti adanya kerugiankerugian yang telah dilalui.

Market Share yang berhasil teraih dari adanya produk baru dapat menambah pemasukan usaha OMG. Pemasukan OMG ini dapat dilakukan dengan strategi pembauran pemasaran untuk mencapai peningkatan target volume penjualan 
produk-produk Usaha Mikro, Kecil dan Menengah (Murdayani et. Al., 2021) (Soehardi, 2021).

\section{KESIMPULAN}

Berdasarkan hasil Analisis Hirarki Proses (AHP) dapat disimpulkan tentang pengembangan usaha. Pengembangan dan kenyamanan membantu meningkatkan teknologi pengolahan madu Teknologi pasca panen, kualitas produksi madu dan peningkatan pengemasan Produk menjadi prioritas utama dalam pengolahan pasca panen Perkembangan bisnis madu OMG. Prioritas kedua adalah Memberikan pengetahuan dan bantuan tentang produk turunan diproduksi oleh lebah madu Apis Dorsata. Sebagai prioritas terakhir di Pengolahan pasca panen memberikan pengetahuan dan memberikan konsultasi untuk meningkatkan kesadaran kolektor penanganan pasca panen dan ramah lingkungan.

Proses AHP. Hal ini dapat dilihat dari data hasil penggunaan proses hirarki (AHP). Strategi Pengembangan Bisnis Madu OMG memasukkan standar strategi pengembangan pemasaran dan standar strategi sebagai tugas utama Menjadi pengembangan pasca panen Prioritas kedua dalam bisnis madu OMG. Ada urutan lain dalam pengembangan bisnis madu Apa yang bisa diterapkan di OMG Promosikan melalui media cetak, elektronik dan sosial hal pertama yang perlu diperhatikan adalah kemudahan menyusun strategi dan bimbingan meningkatkan keterampilan perumus hal ini juga berlaku untuk teknologi pasca panen dan kualitas produksi madu Prioritaskan strategi perbaikan kemasan produk dengan melakukan ini untuk membuka peluang dan memperluas jaringan pasar kerjasama antara pemerintah, lembaga swadaya masyarakat, industri pengolahan, Bank dan universitas prioritas ketiga, strategi Memberikan pengetahuan dan bantuan tentang produk Turunan yang dihasilkan secara istimewa dari lebah madu Apis Dorsata Keempat, memberikan pengetahuan dan strategi pendidikan Tingkatkan kesadaran pemrosesan para kolektor Prioritas pasca panen dan ramah lingkungan kelima.

OMG. Pengembangan usaha madu yang dilakukan oleh OMG adalah berdasarkan atas apa yang menjadi kebutuhan utama dan kebutuhan pokok konsumen dimana produk kecantikan merupakan salah satu produk yang sangat diminati oleh masyarakat dan sangat laku dipasaran.

\section{Saran}

Berdasarakan uraian diatas saran yang dapat penliti berikan adalah:

Keberlanjutan Usaha. Untuk memaksimalkan perkembangan bisnis madu OMG perlu dilakukan upaya peningkatan pengetahuan dan Keterampilan menyeduh madu. Dalam pelaksanaannya Dukungan dan peran pemerintah dan pihak terkait Relevan dalam bentuk penyediaan fasilitas untuk peningkatan kapasitas Pembuatan bir madu dengan menambahkan mixer dalam pelatihan Atau kursus untuk meningkatkan keterampilan menyeduh madu. Untuk melihat manfaat pelaksanaan kegiatan yang sudah dilakukan Disarankan agar pemerintah mulai dari proses awal kegiatan pengolahan pasca panen hingga Tahap pemasaran. Awasi selama fase pemasaran Minimalkan kerugian yang didapat oleh kolektor Dapatkan pengungkapan informasi tentang harga madu. Dari pesta Sektor swasta disarankan memberikan dukungan dalam bentuk relasi Mitra bisnis yang berkelanjutan sehingga mereka dapat 
berbagi informasi Serta mendukung perkembangan bisnis madu OMG.

Promosi. Perlu adanya peningkatan dorongan promosi pengembangan produk kecantikan madu OMG, mulai dari aspek pengolahan produk hingga aspek pemasaran. Perlu adanya penelitian lebih lanjut terkait pengolahan produk dan pemasaran produk kecantikan OMG.

\section{Daftar Pustaka}

Bachri, B. S. (2010). Meyakinkan Validitas Data melalui Triangulasi pada Penelitian Kualitatif.Jurnal Teknologi Pendidikan, Vol.10 No.1, 46-62.

David, Fred R. (2016). Manajemen strategic:Suatu Pendekatan dan Keunggulan Bersaing. Edisi 15.Jakarta: Salemba Empat.

Murdayani, M., Nurbaiti, B., \& Soehardi, S. (2021). The Effect of the Marketing Mix of MSME Products on Sales Volume During the Covid-19 Pandemic The Effect of the Marketing Mix of MSME Products on Sales Volume During the Covid-19 Pandemic. Journal of Strategic and Global Studies, 4(2), 2740.

https://doi.org/https://doi.org/https:/ /doi.org/10.7454/jsgs.v4i2.1043

Rahman, Ayi. (2013). Amazing Madu 147 Resep Madu untuk Membasmi 85 Penyakit. Yogjakarta: Seven Books.

Sarwono, B.(2017). Lebah Madu. Jakarta: AgroMedia Pustaka.

Situmorang, R.O.P. dan Hasanudin, A. (2014). Panduan Manual Budidaya Lebah Madu. Aek Nauli: Balai Penelitian Kehutanan Aek Nauli.

Soehardi, S. (2021b). Model Peningkatan Volume Penjualan Melalui Kualitas Produk, Kualitas Pelayanan Dan Loyalitas Kopi Golda. Jurnal
Manajemen Strategi Dan Aplikasi Bisnis, 4(2), 353-360. https://doi.org/http://ejournal.imperi uminstitute.org/index.php/JMSAB/art icle/view/398

Su'aidy, S., Soehardi, Winarso, W., Syarif, F., \& Untari, D. T. (2021). Supplier Selection of 4oth Container In Pt Tribudhi Pelita Indonesia Using Analytical Hierarchy Process (Ahp) Method. Academy of Strategic Management Journal, 2O(SpecialIssue2), 1-6. SUPPLIER SELECTION OF 4Oth CONTAINER IN PT \%OATRIBUDHI PELITA INDONESIA USING ANALYTICAL \%OAHIERARCHY PROCESS (AHP) METHOD

Taufiqurokhman.(2016). Manajemen Strategik. Jakarta: Fakultas Ilmu Sosial dan Ilmu Politik Universitas Prof. Dr. Moestopo Beraga. 